\title{
The Impact of Privatization on the Performance of the Infrastructure Sector: The Case of Electricity Distribution in Latin American Countries
}

\author{
Luis ANDRES, ${ }^{1}$ Vivien FOSTER, and José Luis GUASCH
}

The World Bank

\begin{abstract}
This paper analyzes the impact of privatization on the performance of 116 electric utilities in ten Latin American countries. The analysis makes a number of contributions to the literature on changes in infrastructure ownership. First, this is the first systemic analysis of the impact of privatization on the distribution of electricity sector. Second, it constructs an unbalanced panel data set of key indicators for each country. Third, it includes a broaderthan in past studies- range of indicators, such as output, employment, productivity, efficiency, quality, coverage, and prices, offering a fuller picture of the effects of privatization on consumers. Fourth, this research covers a longer period of time, and evaluates three stages-before, transition and after-allowing for the identification of the short- and long-run effects of privatization, as opposed to previous analyses' short time series data that do not identify long-run outcomes. Finally, the counterfactual is considered through the analysis in trends. Two different methodologies are applied. The first methodology uses means and medians from each period and tests the significance of the changes between periods. The second methodology consists of an econometric model that captures firm fixed effects, firm-specific time trends and heteroscedasticity corrections. When needed, we used firm-specific time trends to better understand the outcomes. The results suggest that changes in ownership generate significant improvements in labor productivity, efficiency, and product/service quality, and that most of those changes occur in the transition period. Improvements in the post transition period-beyond two years after the change in ownership- are much more modest.
\end{abstract}

\section{World Bank Policy Research Working Paper 3936, June 2006}

The Policy Research Working Paper Series disseminates the findings of work in progress to encourage the exchange of ideas about development issues. An objective of the series is to get the findings out quickly, even if the presentations are less than fully polished. The papers carry the names of the authors and should be cited accordingly. The findings, interpretations, and conclusions expressed in this paper are entirely those of the authors. They do not necessarily represent the view of the World Bank, its Executive Directors, or the countries they represent. Policy Research Working Papers are available online at http://econ.worldbank.org.

\footnotetext{
${ }^{1}$ We are grateful for the helpful comments received from Florencia Borrescio Higa, Carolina Czastkiewicz, Austan Goolsbee, Antonio Estache, Sam Peltzman, Carola Pessino, Chad Syverson and Alejandro Zentner.
} 


\section{Introduction}

Over the last few decades, most countries in Latin America, as part of a structural reform program, brought private participation- privatization, concession, or management change- to previously state-owned enterprises (SOEs). Consequently, private participation in the infrastructure sector increased significantly. ${ }^{2}$ In the electricity distribution sector, only 3 percent of subscribers were served by private companies in the early 1990s, but by 2003 this figure had grown to over 60 percent. Similar patterns can be seen in fixed telecommunications and in water distribution.

Surprisingly, there is little systemic empirical analysis of the impact of these changes on the electricity sector. This can be attributed at least in part to the difficulty of securing appropriate data. Most of the literature on infrastructure privatization focuses on financial indicators, ${ }^{3}$ analyzes case-studies, or evaluates the fixed telecommunications sector. ${ }^{4}$ Existing literature also tends to confine analyses to a narrow time period immediately before and after the change in ownership.

This analysis makes a number of contributions to the literature on changes in infrastructure ownership. First, this is the first analysis of the impact on the distribution of electricity sector. Second it constructs an unbalanced panel data set of key indicators for each country. Third, a broader-than in most past studied- range of indicators is evaluated, including indicators of output, efficiency, labor productivity, quality, coverage, and prices. These indicators offer a fuller picture of the effects of privatization on consumers, as previous studies tend to focus solely on changes in companies' financial performance. Fourth, the analysis covers a longer period of time, and therefore identifies the short- and long-run effects of privatization, as opposed to previous analyses' short time series data that do not identify long-run outcomes. The sample consists of 116 electricity distribution firms that changed ownership during the 1990s. ${ }^{5}$ Finally, the counterfactual-through the use of trend analysis is accounted for and measured against the factual. The analysis consists of two methodologies and is separated into three main periods: "pure public", referring to the three years prior to the announcement of the reform; "transition", starting at the time when the reform was announced and ending one year after the concession or privatization was awarded; and "pure

\footnotetext{
${ }^{2}$ For the purposes of this paper, the term "privatization" refers to private sector participation through sale or divestiture or through concessions.

${ }^{3}$ Some examples are Megginson et al (1994) and D’Sousa and Megginson (1999).

${ }^{4}$ For example, Ros and Baneerjee (1999) analyzed 23 countries in the region in order to evaluate the relationship between privatization, network expansion, and efficiency in telecommunications. Additionally, Ramamurti (1996) examined the privatization of telecommunication and transport in Mexico, Argentina, Jamaica, and Venezuela. Finally, La Porta and Lopez-de-Silanes (1999) evaluated privatized non financial firms in Mexico.

${ }^{5}$ These data are part of a bigger data set used in Andres et al (2006), which contains an analysis of the impact of privatization on fixed telecommunications, electricity and water distribution.
} 
private”, covering the three years after the transition. The first methodology applied is that of Megginson et al. (1994), which uses means and medians from each period and tests the significance of the changes between periods. The second methodology consists of an econometric model that captures firm fixed effects, firm-specific time trends and heteroscedasticity corrections. The importance of firm-specific time trends is illustrated by the results for coverage. The first methodology shows a gradual improvement in average coverage levels, rising $6.9 \%$ from the pure public to transition periods, and $8.7 \%$ from the transition to the pure private period. When the second methodology is applied to capture firm-specific time trends, the growth in coverage shows a different picture: coverage stays roughly the same over the three periods.

The analysis shows that the change in ownership had a significant effect on companies' number of employees, efficiency and quality in the transition period. However, the improvements in the post-transition period- are much more modest. For example, employment, showed important reductions during the transition: The number of employees decreased by $9.9 \%$ per year, totaling a $38.1 \%$ reduction during the transition from the average level of the labor force prior to the transition. However, the pure private period showed a decrease of only $2.1 \%$ per year.

This example typifies the overall picture that emerges of firms' performance as measured by labor productivity, efficiency and quality: an initial dramatic change during the transition period followed by a return to more modest adjustments during the pure private period. Regarding the other indicators analyzed, prices are difficult to compare across companies, and the results were not strong, although they suggest a rise in prices. For coverage and output, privatization produced no changes once the analysis controlled for firm-specific time trends.

The rest of the paper is organized as follows: Section Two contains a summary of the related literature, while Section Three presents the empirical approach and a description of the data that will be used. Section Four describes how the database was built and presents a quick overview of the sample. Section Five characterizes the empirical results, and Section Six presents some comments related to the robustness of the results. Finally, Section Seven summarizes the conclusions.

\section{Review of the Literature}

Most of the literature related to ownership change has focused in other sectors than electricity, such as in transportation (for example, Ramamurti [1996] and Laurin and Bozec [2000]), telecommunications (for example, Ros [1999] and Ramamurti [1996]) and manufacturing (for example, Frydman et al. [1999] and Boarman and Vining [1989]). In the case of privatization 
of the distribution of electricity and water, in particular for Latin American Countries, there is no comprehensive reference. Most of the articles that analyze this issue respond to case-studies or a country analysis (For examples, see Galal et al. [1994] and La Porta and Lopez-de-Silanes [1999]), and only the telecommunications sector has been more deeply analyzed in the region (see for example Ros and Banerjee [2000]). Some exceptions in these sectors are Estache and Rossi (2004) for the case of Electricity Distribution and Galiani et al. (2004) for Water.

Ehrlich et al. (1994) provided good evidence on productivity differences between stateowned and privately owned firms. They used a sample of 23 comparable international airlines of different (and in some cases changing) ownership categories over the period 1973-83 for which they were able to obtain good and comparable cost, output, and ownership data. The researchers developed a model of endogenous, firm-specific productivity growth as a function of firm-specific capital, and used the model as a basis for their fixed-effects regressions estimating a cost function in a simultaneous framework with input-demand equations. They used ownership, ${ }^{6}$ output, ${ }^{7}$ capital quantity and price indices, labor quality and price indices, fuel indices, TFP indices and productivity trends, technical factors, regulatory measures, ${ }^{8}$ and firm and country-specific variables. The study found a significant relationship between ownership and firm-specific rates of productivity growth. The results suggest that private ownership leads to higher rates of productivity growth and declining costs in the long run, and that these differences are not affected by the degree of market competition or regulation.

Boardman and Vining (1989) used data from the 500 largest manufacturing and mining corporations in the world outside the United States, as compiled by Fortune magazine in 1983. They classified these firms as SOEs, Mixed Enterprises or Private Companies, and used four profitability and two efficiency measures. Their results provide evidence that, after controlling for a wide variety of factors, large industrial mixed and public enterprises perform substantially worse than private ones. They also concluded that partial privatizations may be not be the best strategy, since, according to their indicators, these perform quite similarly to SOEs.

Frydman, Gray, Hessel, and Rapaczynski (1999) compared the performance of privatized and state firms in the transition economies of Central Europe, and explicitly tried to control for selection bias. Their study was based on a panel of over 200 privatized and state firms in the Czech Republic, Hungary, and Poland. In particular, their findings show that in the context of Central Europe, privatization has no beneficial effect on any performance measure in the case of firms

\footnotetext{
${ }_{7}^{6}$ Percent of equity owned by the state.

${ }^{7}$ An index of four types of output: scheduled passenger kilometers and scheduled freight, scheduled mail and nonscheduled service ton-km actually flown, all of these weighted by corresponding revenue shares.

${ }^{8}$ Dummies for the regulatory change in the US in 1976 and in the North Atlantic market in 1978.
} 
controlled by insider owners (managers or employees), but that it has a very pronounced effect on firms with outsider owners. In any case, the effects of transferring ownership to insiders and outsiders may have important implications for the design and effectiveness of privatization programs in the transition economies. Second, their study indicates that in those cases in which privatization is effective, its effects vary considerably depending on the performance measure under examination. In particular, their findings show that while the effect of privatization on revenue is very pronounced for certain types of owners, there is no significant effect of ownership change on cost reduction. Finally, by obtaining firm fixed-effect estimates of the various effects of privatization and using different types of control groups, as well as by controlling for changes in the macroeconomic environment, the study attempts to deal with most kinds of selection bias that could potentially affect the results.

Galal et al. (1994) compared the actual post-privatization performance of 12 large firms, mostly airlines and regulated utilities in Britain, Chile, Malaysia, and Mexico, with the predicted performance of those firms that had not been divested. Using this counter-factual approach, the authors documented net welfare gains in 11 of the 12 cases considered, which equal, on average, 26 percent of the firms' pre-divestiture sales. They found no case where workers were significantly worse off, and in three cases, workers significantly benefited.

La Porta and López-de-Silanes (1999) found that the former Mexican SOEs they studied rapidly closed a large performance gap with industry-matched private firms that existed prior to divestment. The former SOEs, which were highly unprofitable before privatization, became very profitable afterward. Output increased by 54.3 percent, in spite of a reduced level of investment spending, and sales per employee roughly doubled. The privatized firms reduced (blue- and whitecollar) employment by half, but those workers who remained were paid significantly more. The authors attribute most of the performance improvement to productivity gains resulting from better incentives, with at most one-third of the improvement being attributable to lower employment costs.

For the case of the electrical sector in Latin America, there are broad descriptions of the reforms in the sector, but without empirical analysis (see for example, Millan et al. [2001], Dussan [1996] and Estache and Rodriguez Pardina [1998]). Other studies focused on developing countries, where some information about Latin America can be found (see for example Bacon and BesantJones [2001]). Finally, the recent review of Joskow (2003) summarizes the lessons learned across countries in the electricity market.

The reason for the lack of empirical analysis is the nonexistence of available systematic data. Still, there is some country analysis for this sector. For example, Chisari et al. (1997) built a 
general equilibrium model in order to analyze the impact of privatizations in Argentina between 1993 and 1995. Among the regional empirical research that can be mentioned is Estache and Rossi (2004). The authors analyzed the impact of change in ownership on labor productivity and prices. They also evaluated how the different regulatory environments affected these outcomes in the region. They found that private firms use significantly less labor to produce a given bundle of output than public firms. Using similar data, Rossi (2004) also analyzed the firms' operating and maintenance expenses. He found that these costs did not change significantly after the reform, and argued that outsourcing, in part, may bias the results for the decrease in labor usage and labor productivity.

\section{Empirical Approach: Methodology}

Ideally, to evaluate the impact of privatization, the performance of a utility under private operation should be compared to the performance of its public "counterfactual”, a comparable firm in a similar environment that is still operated by the government. In most cases, it is hard to identify a comparable firm; hence, most of the literature compares the evolution of selected indicators before and after the change in ownership.

The majority of the literature employs two different methodologies in order to estimate the effects of privatization: The first methodology began with Megginson et al. (1994); and several subsequent studies have used the same approach to measure means and medians of the periods before and after privatization and test the significance of the change between the periods. This methodology has also been applied in studies that considered different samples of SOEs among countries and compared their performance to privatized firms. The second methodology is found in another branch of literature that assumes privatization policies to be an intervention. Following the literature of program evaluation (see Heckman et al. [1985]), this approach proposes a dummy for those periods where the SOE was privately owned, and checks the significance of this dummy, as well as the significance of various interactions specific to each paper (for example, Boardman and Vining [1989] and Ros [1999]).

This paper follows both methodologies. For the first approach, the analysis is split into three main periods: First, the "pure public" period, covering the three years before transition; second, the "transition” period, starting when the reform was announced and ending one year after the concession or privatization was awarded; and third, the three years after the transition, or the "pure private" period. The changes in average levels and growths are analyzed, and the average 
changes between periods are computed. The paper concludes by testing the significances of the changes in means and medians.

For the second approach, we start with a simple version of the model, as specified below:

$$
\ln \left(y_{i j t}\right)=\beta_{0} P R I V_{i j t}+\sum_{i j} \phi_{i j} D_{i j}+v_{i j t}
$$

where $y_{i j t}$ are the variables of interest (outputs, number of employees, labor productivity, efficiency, quality, coverage and prices). The main coefficient in this model is the dummy, $P R I V_{i j t}$, that is equal to one if the firm $i$ of country $j$ has private owners at time $t$. Given the fact that there are several variables not observable to the econometrician, fixed effects are included to capture the firm's characteristics (e.g. management, initial conditions, size, density of the network, etc.), which are assumed to be constant for each firm across time. Hence, $\beta_{0}$ will capture the effect of the privatization or concession on the outcome of interest. As was pointed out by Frydman et al. (1999), adding the firm fixed effects may reduce the selection bias of the firms in the sample. Finally, $\phi_{i j}$ captures fixed effects defined by $D_{i j}$.

A second version of equation (1) will also be estimated, introducing a firm-specific time trend:

$$
\ln \left(y_{i j t}\right)=\beta_{0} P R I V_{i j t}+\sum_{i j} \phi_{i j} D_{i j}+\sum_{i j} \phi_{i j} t_{i j}+v_{i j t}
$$

Equation (2) contains the same dependent variables and dummy used in the static model, $P R I V_{i j t}$. The third coefficient will capture the time trend of the variable of interest. Several factors may affect this, such as initial conditions. Hence, it is important to control for the firm's specific fixed effects to capture the characteristics of the firm not observed by the econometrician. As in the previous model, we will include fixed effects. Again, the relevant coefficient will be $\beta_{0}$, which will capture the effect of the privatization or the concession on the outcome of interest.

Figure 1 illustrates this issue. The first graph shows actual aggregated data for number of connections per utility for Latin America. It also marks the three period studies in this research. The second and third graphs illustrate the difference of measuring the impact of privatization without and with firm specific time trends corrections. As these graphs show, it is clear that indicators that for some indicator such as output and coverage, it is misleading the interpretation of the results when the firm-specific time trends are not considered. 
Figure 1: Example of estimation without and with firms-specific time trend correction - Average Number of connections for Latin America.
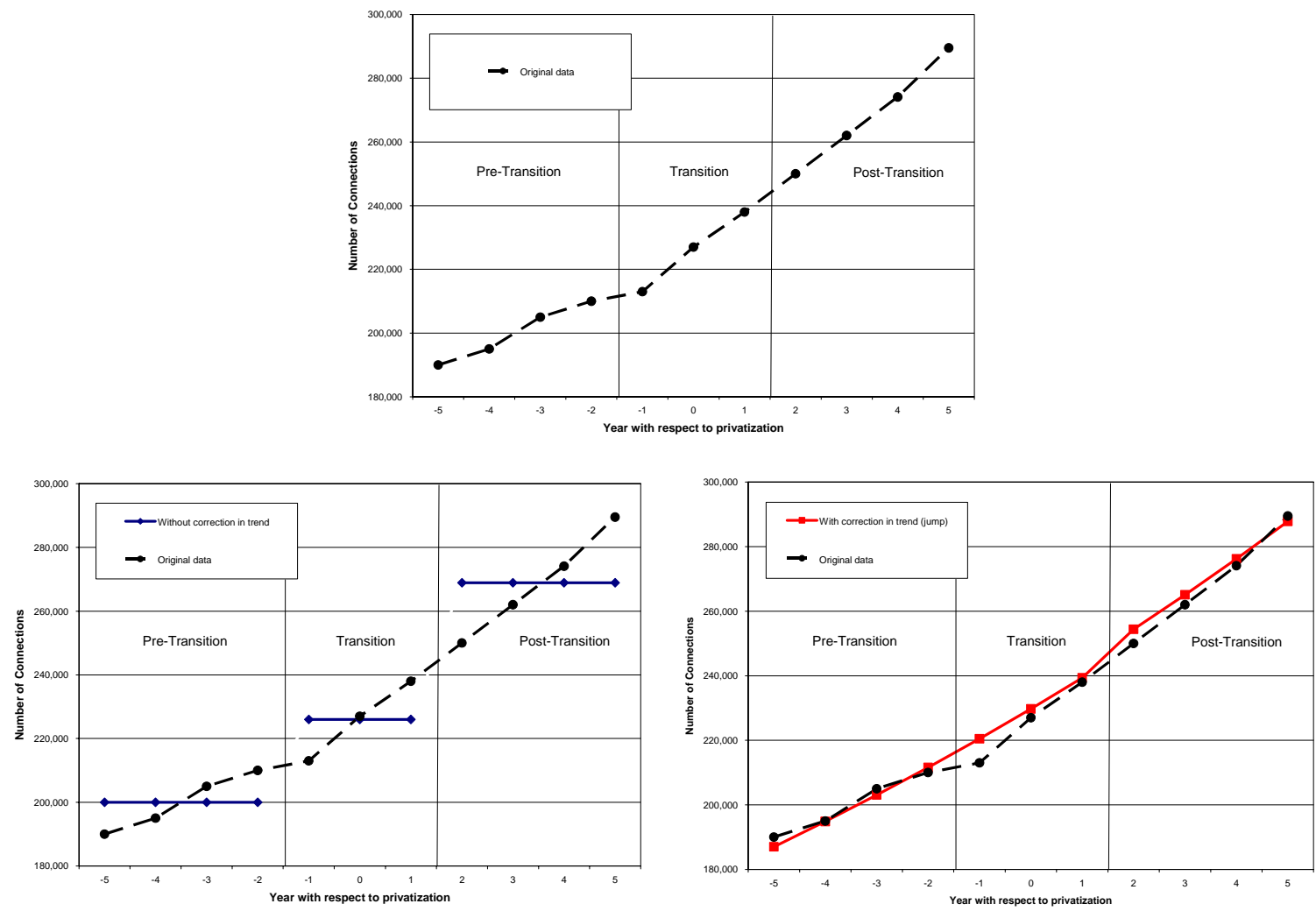

Source: Authors' elaboration based on the data described in section IV.

Moreover, as will be described later, the transition period has some important effects on firms. Most of the literature reviewed uses a basic approach similar to that in equation (1), and in some cases accounts for specifications like those included in equation (2). In other words, the firm is evaluated immediately before and after the change in ownership. This approach does not account for changes that may occur in preparation for the change in ownership or in response to it, perhaps through one-time decisions (e.g. a reduction in personnel). In this paper, in order to isolate and identify the outcomes during the period around the change in ownership, specific dummies are defined for these transitional years. The transition period is defined the same way as in the first approach: from announcement of the change in ownership through one year after the privatization or concession is awarded. Since it is not clear for all the cases when the process to change 
ownership was announced, we will assume that it started two years prior to the date of the award. ${ }^{9}$ Therefore, we can define a dummy for the transition and a dummy for the post-transition period, so that Equations (1) and (2) become:

$$
\begin{gathered}
\ln \left(y_{i j t}\right)=\delta^{T} D U M M Y_{-} T R A N_{i j t}+\delta^{P} D U M M Y_{-} P O S T_{i j t}+\sum_{i j} \phi_{i j} D_{i j}+v_{i j t} \\
\ln \left(y_{i j t}\right)=\delta^{T} D U M M Y_{-} T R A N_{i j t}+\delta^{P} D U M M Y_{-} P O S T_{i j t}+\sum_{i j} \phi_{i j} D_{i j}+\sum_{i j} \theta_{i j} t_{i j}+v_{i j t}
\end{gathered}
$$

where

$$
D U M M Y_{-} T R A N_{i j t}\left\{\begin{array}{cc}
1 & \text { if }-2 \leq \mathrm{s}_{\mathrm{ijt}} \leq+1 \\
0 & \text { otherwise }
\end{array}\right.
$$

and

$$
D U M M Y_{-} P O S T_{i j t}\left\{\begin{array}{cc}
1 & \text { if } \mathrm{s}_{i j t} \geq 2 \\
0 & \text { otherwise }
\end{array}\right.
$$

where $S_{i j t}$ is a time trend that has a value equal to zero for the year when the privatization was awarded. In this sense, the first dummy will identify the average change in the dependent variable during the transition with respect to the average level prior to the transition years, during the pure public period. The second dummy will identify the average change of the dependent variable after the transition with respect to the pure public period.

The first basic specification will be equations (1') and (2') using the log level of the indicators. In particular, this will help to identify most of the conclusions. For those variables that present trends (for example, number of connections), equation (2') will be more enlightening. However, it relies on the assumption that trends among the three periods of analysis are the same. In order to relax this assumption, we will run a third set of equations (1'), but using the annual growth in each indicator. In this case, the first equation will identify average changes in growth between the periods.

Given the fact that we are using a semi-logarithmic functional form of these models for each of the indicators, it should be remembered that the percentage impact in each indicator is given by $e^{\delta}-1$ (Halvorsen and Palmquist [1980]) when interpreting the coefficient estimates of the dummy.

\footnotetext{
${ }^{9}$ We have performed a review of this arbitrary period definition with several country analysts, and this criteria seems to respond to most of the cases.
} 
In order to correct for potential nonspherical errors, a Generalized Least Square (GLS) approach would be appropriate. However, the GLS estimation requires knowledge of the unconditional variance matrix of $v_{i j t}, \Omega$, up to scale. Hence, we must be able to write $\Omega=\sigma^{2} C$, where $C$ is a known GxG positive definite matrix. But, in this case, as this matrix is not known, we will follow a Feasible GLS (FGLS) approach that replaces the unknown matrix $\Omega$ with a consistent estimator.

\section{Data}

This research required the construction of an unbalanced panel data set of key indicators for utilities in LAC in electricity distribution. For this, we used official data reported by firms to their investors and statistical reports of the regulator agencies of each country. Furthermore, information was requested from each firm as well as from each regulatory office. Additional sources used include OLADE (Latin American Organization of Energy) publications. A particular effort was made to corroborate the data provided by the firms with several public sources and with data on the firms provided by different governmental offices. In addition, careful attention was paid to ensure the consistency and comparability of the data over time and across countries. ${ }^{10}$

The analysis focuses on several indicators of outcomes, employment, labor productivity, efficiency, quality, coverage and prices. Table 1 presents the definitions of the variables used in the present analysis and Table 2 presents the summary statistics of the variables used.

Some of these variables have been used by other authors in other samples, such as Ros (1999), who used equivalent indicators for coverage, labor productivity, quality and prices but for the telecommunications sector. Ramamurti (1996) used analogous indicators in output, coverage and labor productivity for the four Latin American telecommunications firms of his study. Saal and Parker (2001) used similar indicators for output, employment, quality and prices, but for water and sewerage companies of England and Wales.

The countries analyzed were Argentina, Bolivia, Brazil, Chile, Colombia, El Salvador, Guatemala, Nicaragua, Panama, and Peru. The sample consists of unbalanced panel data that includes 116 firms and 1,103 firm-year observations. Each of the firms included in the sample contains at least one year of pre privatization data. In fact, 98 of the 116 firms have information for at least the previous three years.

\footnotetext{
${ }^{10}$ As quality indexes vary across countries, we collected the closest indexes in order to be able to compare their evolution across time, rather than the absolute level.
} 
Table 1: Definition of the variables

\begin{tabular}{lll}
\hline \hline & & Electricity Distribution \\
\hline Output & $\bullet$ & Total number of subscribers (residential and non-residential). December of each year \\
\hline Labor & $\bullet$ & Total energy sold per year (in MWHs) \\
\hline Labor Productivity & $\bullet$ & Number of subscribers per employee \\
& $\bullet$ & Total energy sold each year per employee \\
\hline Efficiency & $\bullet$ & Energy lost in the distribution (due to technical losses and illegal connections) \\
\hline Quality & $\bullet$ & Average duration of interruptions per consumer (hours/year) \\
& $\bullet$ & Average frequency of interruptions per consumer (\#/year) \\
\hline Coverage & $\bullet$ & Number residential subscribers per 100 households \\
\hline Prices & $\bullet$ & Average tariff for 1 MWH for a residential service in dollars (it includes fixed and \\
& & variable costs) (December of each year). \\
\hline \hline
\end{tabular}

Table 2: Summary Statistics

\begin{tabular}{|c|c|c|c|c|c|c|}
\hline Variable & $\mathrm{N}$ & Mean & Median & SD & Min & $\overline{M a x}$ \\
\hline \multicolumn{7}{|l|}{ Electricity Distribution } \\
\hline Number of subscribers & 98 & 497,776 & 225,230 & 681,698 & 2,700 & $3,884,579$ \\
\hline Output [thousand of KWHs] & 100 & 2,850 & 789.5 & 5,282 & 13.8 & 34,300 \\
\hline Number of employees & 87 & 1,421 & 625 & 2,115 & 18 & 13,642 \\
\hline Subscribers per employee & 84 & 558.81 & 506.67 & 244.20 & 210.45 & $1,523.27$ \\
\hline Output per employee & 84 & $2,343.48$ & $2,116.46$ & $1,298.60$ & 663.86 & $7,323.09$ \\
\hline Distributional losses & 90 & $15.3 \%$ & $13.6 \%$ & $6.6 \%$ & $2.0 \%$ & $33.9 \%$ \\
\hline Duration of interruptions per subscriber & 65 & 25.26 & 20.36 & 21.01 & 1.75 & 100.00 \\
\hline Frequency of interruptions per subscriber & 67 & 22.63 & 16.03 & 21.24 & 1.07 & 100.00 \\
\hline Subscribers per $100 \mathrm{HHs}$ & 86 & $74.6 \%$ & $81.3 \%$ & $20.7 \%$ & $7.0 \%$ & $100.0 \%$ \\
\hline Avg price per KWH [in u\$s] & 92 & 88.70 & 85.34 & 35.43 & 7.47 & 323.61 \\
\hline
\end{tabular}

\section{Empirical Results}

\section{V.1. Mean and Median Analysis}

In this section, the research is basically split between the changes in the levels and the changes in trends for each of the indicators. Note that for some indicators it is more interesting to analyze the changes in trends, like the case of the evolution of labor productivity and coverage, while there are other variables for which it is more relevant to analyze changes in levels, such as quality and prices. Yet the complete set of results will be presented in both forms: changes in levels and in growths. 
The analysis will be separated into three main periods: "pure public," referring to the three years prior to the announcement of the reform; "transition," starting at the time when the reform was announced and ending one year after the concession or privatization was awarded; and "pure private," covering the three years after the transition. The basic idea of this segmentation is to be able to identify the direct effects of the process of reform on the firm, such as preparation of the firm to be sold, and factors such as reduced incentives for public managers to perform well before the anticipated change in ownership. In addition to this, we assume that private intervention may not have immediate effects, due to lag time before the first investment, managerial decisions such as investment timing in order to expand the network or decisions related to the improvement of the quality and efficiency of the network.

Tables 3 and 4 present the results for electricity distribution. In order to do this analysis, the series were initially normalized, defining the value 100 for the first year when the firm was privately owned. The tables present the average level (or growth) of each normalized indicator for the three periods of analysis in columns (1) to (3). Columns (4) through (6) show the average change in levels (growth) between these three periods: column (4) presents the difference between the transition average level (growth) and that of the pure public period. ${ }^{11}$ Column (5) presents the average change in levels (growth) from the transition to the pure private period while column (6) presents the total change in levels (growth) since the pure public period. For each indicator, the tables present the mean, median, standard deviation and number of firms included in the analysis. Finally, columns (7) to (9) show the results of the test of the differences in means and medians of the average levels (growth).

\footnotetext{
${ }^{11}$ Note that in order to avoid the problems that arise in cases when there are different companies across periods, we first calculate the difference within each firm, and then the average difference between periods is calculated.
} 
Table 3: Means and Medians Analysis in Levels

\begin{tabular}{|c|c|c|c|c|c|c|c|c|c|c|}
\hline \multirow[t]{2}{*}{ Variable } & \multirow[t]{2}{*}{ stats } & \multicolumn{3}{|c|}{ Mean } & \multicolumn{3}{|c|}{ Diff in Levels } & \multicolumn{3}{|c|}{$\begin{array}{l}\text { T-stat (Z-stat) for difference } \\
\text { in means (medians) in Levels }\end{array}$} \\
\hline & & $\begin{array}{l}\text { Preprivat } \\
\text { (1) } \\
\end{array}$ & $\begin{array}{c}\text { Transition } \\
(2) \\
\end{array}$ & $\begin{array}{c}\text { Postprivat } \\
\text { (3) } \\
\end{array}$ & $\begin{array}{c}(2)-(1) \\
(4) \\
\end{array}$ & $\begin{array}{c}(3)-(2) \\
(5) \\
\end{array}$ & $\begin{array}{c}(3)-(1) \\
(6) \\
\end{array}$ & $\begin{array}{c}(2)-(1) \\
(7)\end{array}$ & $\begin{array}{c}(3)-(2) \\
(8) \\
\end{array}$ & $\begin{array}{c}(3)-(1) \\
(9)\end{array}$ \\
\hline \multicolumn{11}{|l|}{ Outputs } \\
\hline Residential & mean & 85.83 & 102.26 & 120.48 & 17.32 & 17.11 & 35.16 & 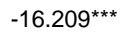 & $-17.493^{\star \star \star}$ & $-16.809 * \star \star$ \\
\hline \multirow[t]{3}{*}{ Connections } & p50 & 85.94 & 102.00 & 119.59 & 17.11 & 16.55 & 34.33 & $-7.843^{\star \star \star}$ & $-7.306^{\star \star \star}$ & -7.459 *** \\
\hline & sd & 9.20 & 2.53 & 10.04 & 9.68 & 8.76 & 16.94 & & & \\
\hline & $\mathrm{N}$ & 82 & 116 & 74 & 82 & 74 & 71 & & & \\
\hline \multirow{4}{*}{$\begin{array}{l}\text { MWH sold } \\
\text { per year }\end{array}$} & mean & 82.29 & 102.67 & 119.22 & 20.82 & 15.60 & 36.74 & $-13.119^{\star \star \star}$ & $-11.882^{\star \star \star}$ & $-7.554^{\star \star \star}$ \\
\hline & p50 & 82.59 & 101.20 & 117.13 & 19.88 & 15.17 & 34.60 & $-7.399^{\star \star \star}$ & $-6.945^{\star \star \star}$ & $-6.128^{\star \star \star}$ \\
\hline & sd & 14.11 & 6.44 & 21.12 & 14.28 & 17.77 & 25.69 & & & \\
\hline & $\mathrm{N}$ & 81 & 116 & 74 & 81 & 74 & 69 & & & \\
\hline \multicolumn{11}{|l|}{ Inputs } \\
\hline Number of & mean & 162.71 & 100.65 & 86.59 & -61.37 & -14.27 & -78.19 & $8.949 * \star \star$ & $8.678^{\star \star \star}$ & $5.432^{\star \star \star}$ \\
\hline \multirow[t]{3}{*}{ Employees } & p50 & 147.46 & 100.00 & 86.17 & -48.38 & -14.76 & -63.63 & $6.252^{\star \star \star}$ & $5.903^{\star \star \star}$ & $5.057^{\star \star \star}$ \\
\hline & sd & 54.42 & 6.76 & 23.63 & 52.22 & 20.18 & 63.71 & & & \\
\hline & $\mathrm{N}$ & 58 & 116 & 59 & 58 & 59 & 50 & & & \\
\hline \multicolumn{11}{|l|}{ Efficiency } \\
\hline \multirow{4}{*}{$\begin{array}{l}\text { Connections } \\
\text { per employee }\end{array}$} & mean & 60.24 & 103.33 & 147.42 & 45.38 & 40.83 & 88.62 & $-14.738^{\star \star \star}$ & $-13.344^{\star \star \star}$ & $-9.334^{\star \star *}$ \\
\hline & p50 & 59.90 & 100.00 & 135.26 & 44.65 & 32.10 & 88.86 & $-6.543^{\star \star \star}$ & $-6.093^{\star \star \star}$ & $-6.438^{\star \star \star}$ \\
\hline & sd & 18.65 & 9.86 & 42.10 & 23.25 & 33.31 & 46.49 & & & \\
\hline & $\mathrm{N}$ & 57 & 116 & 58 & 57 & 58 & 49 & & & \\
\hline GWH per & mean & 58.56 & 103.97 & 145.09 & 47.50 & 37.64 & 86.27 & $-17.097^{\star \star \star}$ & $-11.362^{\star \star \star}$ & $-6.901^{\star \star \star}$ \\
\hline \multirow[t]{3}{*}{ employee } & p50 & 59.68 & 100.00 & 129.76 & 46.04 & 26.76 & 71.15 & $-6.567^{\star \star \star}$ & $-6.093^{\star \star \star}$ & $-6.182^{* * *}$ \\
\hline & sd & 18.58 & 11.98 & 53.86 & 20.98 & 41.54 & 53.15 & & & \\
\hline & $\mathrm{N}$ & 57 & 116 & 58 & 57 & 58 & 49 & & & \\
\hline \multirow{4}{*}{$\begin{array}{l}\text { Distributional } \\
\text { losses }\end{array}$} & mean & 112.19 & 98.73 & 87.78 & -12.92 & -9.75 & -25.14 & $3.658^{\star \star \star}$ & $4.657^{\star \star \star}$ & $3.515^{\star \star \star}$ \\
\hline & p50 & 104.37 & 100.00 & 85.34 & -6.13 & -11.06 & -19.93 & $3.268^{\star \star \star}$ & $4.272^{\star \star \star}$ & $3.341^{\star \star \star}$ \\
\hline & sd & 26.96 & 7.33 & 26.03 & 27.14 & 21.12 & 37.79 & & & \\
\hline & $\mathrm{N}$ & 59 & 116 & 58 & 59 & 58 & 49 & & & \\
\hline \multicolumn{11}{|l|}{ Quality } \\
\hline Duration of & mean & 134.49 & 100.34 & 72.42 & -30.61 & -25.32 & -41.34 & 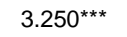 & $2.687^{\star \star \star}$ & $3.782^{\star \star \star}$ \\
\hline Interruptions & p50 & 123.37 & 100.00 & 65.42 & -24.11 & -30.41 & -34.37 & $3.477^{\star \star \star}$ & $3.143^{\star \star *}$ & $4.019 * \star \star$ \\
\hline per year & sd & 67.57 & 20.00 & 42.58 & 57.28 & 41.80 & 75.35 & & & \\
\hline per consumer & $\mathrm{N}$ & 37 & 116 & 39 & 37 & 39 & 24 & & & \\
\hline Frequency of & mean & 132.59 & 98.63 & 82.71 & -34.90 & -13.65 & -31.66 & $4.256^{\star \star \star}$ & 1.300 & 1.078 \\
\hline Interruptions & p50 & 119.54 & 100.00 & 67.96 & -21.20 & -29.20 & -32.86 & $3.809 * \star *$ & $3.571^{\star \star *}$ & $4.326^{\star \star *}$ \\
\hline per year & sd & 57.83 & 13.77 & 93.00 & 49.88 & 79.05 & 119.29 & & & \\
\hline per consumer & $\mathrm{N}$ & 37 & 116 & 39 & 37 & 39 & 24 & & & \\
\hline \multicolumn{11}{|l|}{ Coverage } \\
\hline Residential & mean & 94.93 & 101.17 & 110.66 & 6.93 & 8.67 & 16.46 & $-6.886^{\star \star \star}$ & $-8.162^{\star \star \star}$ & $-8.333^{\star \star \star}$ \\
\hline Connections & p50 & 95.35 & 100.00 & 108.92 & 5.60 & 7.62 & 14.16 & $-6.016^{\star \star \star}$ & $-6.110^{* * *}$ & $-6.323^{\star * \star}$ \\
\hline \multirow[t]{2}{*}{ per $100 \mathrm{HHs}$} & sd & 7.91 & 2.22 & 10.09 & 8.42 & 8.26 & 15.09 & & & \\
\hline & $\mathrm{N}$ & 70 & 116 & 63 & 70 & 63 & 56 & & & \\
\hline \multicolumn{11}{|l|}{ Prices } \\
\hline Avg Tariff per & mean & 106.24 & 98.48 & 94.87 & -9.49 & -2.88 & -9.91 & $3.305^{\star \star \star}$ & $2.808^{\star \star \star}$ & $1.313^{*}$ \\
\hline residential GWH & p50 & 97.85 & 100.00 & 95.61 & -0.09 & -1.38 & -16.37 & $2.437^{\star \star}$ & $2.690^{\star \star \star}$ & $1.702^{*}$ \\
\hline (in dollars) & sd & 23.68 & 7.52 & 24.63 & 23.85 & 18.73 & 26.18 & & & \\
\hline & $\mathrm{N}$ & 69 & 116 & 73 & 69 & 73 & 55 & & & \\
\hline Avg Tariff per & mean & 91.77 & 100.81 & 109.61 & 9.21 & 8.46 & 17.90 & $-5.164^{\star \star \star}$ & $-5.143^{\star \star \star}$ & $-5.067^{\star \star \star}$ \\
\hline residential GWH & p50 & 88.27 & 100.00 & 107.07 & 15.25 & 4.64 & 24.26 & $-4.774^{\star \star *}$ & $-4.181^{* \star *}$ & $-4.643^{\star \star *}$ \\
\hline (in real local & sd & 12.83 & 4.97 & 18.59 & 14.81 & 14.27 & 25.81 & & & \\
\hline currency) & $\mathrm{N}$ & 69 & 116 & 73 & 69 & 73 & 55 & & & \\
\hline
\end{tabular}


Table 4: Means and Medians Analysis in Growth

\begin{tabular}{|c|c|c|c|c|c|c|c|c|c|c|}
\hline \multirow[t]{2}{*}{ Variable } & \multirow[t]{2}{*}{ stats } & \multicolumn{3}{|c|}{ Avg. Annual Growth } & \multicolumn{3}{|c|}{ Annual Diff in growth } & \multicolumn{3}{|c|}{$\begin{array}{l}\text { T-stat (Z-stat) for difference } \\
\text { in means (medians) in growth }\end{array}$} \\
\hline & & $\begin{array}{l}\text { Preprivat } \\
\text { (1) }\end{array}$ & $\begin{array}{c}\text { Transition } \\
\text { (2) } \\
\end{array}$ & $\begin{array}{c}\text { Postprivat } \\
\text { (3) }\end{array}$ & $\begin{array}{c}(2)-(1) \\
(4)\end{array}$ & $\begin{array}{c}(3)-(2) \\
(5)\end{array}$ & $\begin{array}{c}(3)-(1) \\
(6)\end{array}$ & $\begin{array}{c}(2)-(1) \\
(7) \\
\end{array}$ & $\begin{array}{c}(3)-(2) \\
(8)\end{array}$ & $\begin{array}{c}(3)-(1) \\
(9) \\
\end{array}$ \\
\hline \multicolumn{11}{|l|}{ Outputs } \\
\hline Residential & mean & $4.3 \%$ & $5.5 \%$ & $3.4 \%$ & $1.3 \%$ & $-2.8 \%$ & $-0.8 \%$ & $-1.787^{\star \star}$ & $3.590 * \star \star$ & $1.976^{\star \star}$ \\
\hline \multirow{3}{*}{ Connections } & p50 & $4.4 \%$ & $4.7 \%$ & $3.2 \%$ & $0.4 \%$ & $-1.7 \%$ & $-1.0 \%$ & -1.456 & $5.116^{\star \star \star}$ & $2.366^{\star \star}$ \\
\hline & sd & $2.6 \%$ & $5.5 \%$ & $2.0 \%$ & & & & & & \\
\hline & $\mathrm{N}$ & 79 & 84 & 60 & 79 & 60 & 56 & & & \\
\hline \multirow{4}{*}{$\begin{array}{l}\text { MWH sold } \\
\text { per year }\end{array}$} & mean & $6.7 \%$ & $6.7 \%$ & $3.2 \%$ & $-0.5 \%$ & $-5.0 \%$ & $-3.2 \%$ & 0.616 & $3.085^{\star \star \star}$ & $3.362^{\star \star \star}$ \\
\hline & p50 & $6.6 \%$ & $5.9 \%$ & $2.8 \%$ & $-0.7 \%$ & $-2.9 \%$ & $-2.7 \%$ & 0.708 & $4.096^{\star \star \star}$ & $3.159 * \star \star$ \\
\hline & sd & $4.5 \%$ & $8.7 \%$ & $4.7 \%$ & & & & & & \\
\hline & $\mathrm{N}$ & 74 & 85 & 57 & 74 & 57 & 51 & & & \\
\hline \multicolumn{11}{|l|}{ Inputs } \\
\hline Number of & mean & $-6.6 \%$ & $-9.9 \%$ & $-2.1 \%$ & $-3.2 \%$ & $9.7 \%$ & $2.1 \%$ & $2.056^{\star}$ & $-5.398^{\star \star \star}$ & $-1.519 *$ \\
\hline \multirow[t]{3}{*}{ Employees } & p50 & $-6.1 \%$ & $-9.0 \%$ & $-1.8 \%$ & $-3.8 \%$ & $8.7 \%$ & $4.0 \%$ & $2.306^{\star \star}$ & $-4.505^{\star \star \star}$ & $-1.776^{*}$ \\
\hline & sd & $8.1 \%$ & $10.0 \%$ & $4.8 \%$ & & & & & & \\
\hline & $\mathrm{N}$ & 53 & 69 & 44 & 53 & 44 & 32 & & & \\
\hline \multicolumn{11}{|l|}{ Efficiency } \\
\hline \multirow{4}{*}{$\begin{array}{l}\text { Connections } \\
\text { per employee }\end{array}$} & mean & $13.4 \%$ & $18.4 \%$ & $5.5 \%$ & $4.2 \%$ & $-16.4 \%$ & $-4.2 \%$ & $-1.813^{\star \star}$ & $5.691^{\star \star \star}$ & $2.183^{\star \star}$ \\
\hline & p50 & $11.1 \%$ & $14.0 \%$ & $5.6 \%$ & $4.5 \%$ & $-10.6 \%$ & $-3.5 \%$ & $2.333^{\star \star}$ & $4.975^{\star \star \star}$ & $2.300 * \star$ \\
\hline & sd & $12.6 \%$ & $16.8 \%$ & $5.1 \%$ & & & & & & \\
\hline & $\mathrm{N}$ & 53 & 66 & 43 & 53 & 43 & 32 & & & \\
\hline \multirow{4}{*}{$\begin{array}{l}\text { GWH per } \\
\text { employee }\end{array}$} & mean & $15.1 \%$ & $20.3 \%$ & $5.5 \%$ & $3.7 \%$ & $-19.9 \%$ & $-6.7 \%$ & $1.426^{*}$ & $6.539 * \star \star$ & $2.826^{\star \star \star}$ \\
\hline & p50 & $12.8 \%$ & $15.0 \%$ & $4.0 \%$ & $3.0 \%$ & $-16.4 \%$ & $-6.3 \%$ & -1.624 & $5.084^{\star \star \star}$ & $3.011^{\star \star \star}$ \\
\hline & sd & $13.5 \%$ & $16.9 \%$ & $7.6 \%$ & & & & & & \\
\hline & $\mathrm{N}$ & 53 & 66 & 43 & 53 & 43 & 32 & & & \\
\hline \multirow{4}{*}{$\begin{array}{l}\text { Distributional } \\
\text { losses }\end{array}$} & mean & $0.6 \%$ & $-5.5 \%$ & $-1.3 \%$ & $-4.7 \%$ & $6.4 \%$ & $-2.0 \%$ & $3.301^{\star \star \star}$ & $-3.474^{\star \star \star}$ & 0.960 \\
\hline & p50 & $0.1 \%$ & $-4.9 \%$ & $-0.1 \%$ & $-4.5 \%$ & $6.5 \%$ & $-1.5 \%$ & $3.317^{\star \star *}$ & $-2.944^{\star \star \star}$ & 0.786 \\
\hline & sd & $7.8 \%$ & $10.2 \%$ & $9.6 \%$ & & & & & & \\
\hline & $\mathrm{N}$ & 57 & 73 & 46 & 57 & 46 & 36 & & & \\
\hline \multicolumn{11}{|l|}{ Quality } \\
\hline Duration of & mean & $4.1 \%$ & $-9.8 \%$ & $-3.8 \%$ & $-11.2 \%$ & $3.4 \%$ & $-10.5 \%$ & $1.788^{\star}$ & $4.476^{\star \star \star}$ & $5.122^{\star \star \star}$ \\
\hline Interruptions & p50 & $-5.2 \%$ & $-12.9 \%$ & $-3.2 \%$ & $-7.0 \%$ & $8.5 \%$ & $-5.1 \%$ & $2.132^{\star \star}$ & -0.749 & 0.711 \\
\hline per year & sd & $31.6 \%$ & $25.7 \%$ & $24.8 \%$ & & & & & & \\
\hline per consumer & $\mathrm{N}$ & 32 & 51 & 26 & 32 & 26 & 11 & & & \\
\hline Frequency of & mean & $2.7 \%$ & $-10.6 \%$ & $-11.4 \%$ & $-11.1 \%$ & $-2.9 \%$ & $-17.8 \%$ & $1.653^{*}$ & 0.378 & $3.093^{\star \star \star}$ \\
\hline Interruptions & p50 & $-5.0 \%$ & $-10.8 \%$ & $-6.6 \%$ & $-2.8 \%$ & $-2.4 \%$ & $-14.4 \%$ & $1.664^{*}$ & -0.165 & $2.490^{\star \star}$ \\
\hline per year & sd & $29.0 \%$ & $20.3 \%$ & $20.5 \%$ & & & & & & \\
\hline per consumer & $\mathrm{N}$ & 32 & 51 & 26 & 32 & 26 & 11 & & & \\
\hline \multicolumn{11}{|l|}{ Coverage } \\
\hline Residential & mean & $2.0 \%$ & $2.2 \%$ & $1.9 \%$ & $0.4 \%$ & $-1.0 \%$ & $-0.6 \%$ & -0.903 & $1.702^{\star \star}$ & 0.780 \\
\hline Connections & p50 & $1.5 \%$ & $1.9 \%$ & $1.3 \%$ & $0.4 \%$ & $-0.9 \%$ & $-0.3 \%$ & -1.408 & $3.186^{\star \star \star}$ & 0.619 \\
\hline \multirow[t]{2}{*}{ per $100 \mathrm{HHs}$} & sd & $3.9 \%$ & $3.0 \%$ & $3.6 \%$ & & & & & & \\
\hline & $\mathrm{N}$ & 65 & 76 & 50 & 65 & 50 & 42 & & & \\
\hline \multicolumn{11}{|l|}{ Prices } \\
\hline Avg Tariff per & mean & $9.3 \%$ & $-3.3 \%$ & $2.0 \%$ & $-15.2 \%$ & $4.3 \%$ & $-11.4 \%$ & $6.251^{\star \star \star}$ & $-' 1.821^{\star \star}$ & $3.172^{\star \star \star}$ \\
\hline residential GWH & p50 & $9.7 \%$ & $-6.3 \%$ & $0.1 \%$ & $-15.1 \%$ & $1.3 \%$ & $-13.1 \%$ & 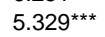 & -1.442 & $2.785^{\star \star \star}$ \\
\hline (in dollars) & sd & $16.0 \%$ & $9.0 \%$ & $14.1 \%$ & & & & & & \\
\hline & $\mathrm{N}$ & 59 & 86 & 57 & 59 & 57 & 35 & & & \\
\hline Avg Tariff per & mean & $10.2 \%$ & $2.0 \%$ & $0.6 \%$ & $-7.8 \%$ & $0.2 \%$ & $-12.3 \%$ & $4.744^{\star \star \star}$ & -0.172 & $4.899^{\star \star \star}$ \\
\hline residential GWH & p50 & $5.9 \%$ & $2.3 \%$ & $1.8 \%$ & $-5.3 \%$ & $0.9 \%$ & $-9.7 \%$ & $4.454^{\star \star \star}$ & -0.734 & $4.063^{\star \star \star}$ \\
\hline (in real local & sd & $12.6 \%$ & $7.3 \%$ & $7.9 \%$ & & & & & & \\
\hline currency) & $\mathrm{N}$ & 59 & 86 & 56 & 59 & 56 & 35 & & & \\
\hline
\end{tabular}

\section{A. Output}

The first output indicator, number of connections, had important increases during the three periods: Levels of residential connections showed a $20.2 \%$ increase from the pure public to the transition period, and a $16.7 \%$ increase from transition to pure private. But a closer look at the results shows a clearly positive trend that would exist in the absence of a change in ownership. In terms of growth rates, residential connections' growth increased by 1.3 percent points during the transition, from it average annual growth rate of $4.3 \%$ during the first period, but then growth 
slowed to 3.4\% per year. The other indicator of output, energy supplied to the network, suffered a deceleration after the transition. As will be seen later, a justification for this can be driven by the improvement in efficiency caused by the reduction of distributional losses, as well as due some increases in average real prices.

\section{B. Number of Employees}

Most of the SOEs were characterized by being oversized in personnel. Hence, as expected, an important reduction in the number of employees was clearly observed. Moreover, the literature also found that, in some cases, the government decided to reduce the number of employees in order to increase the value of the firms (Chong and Lopez-de-Silanes [2003b]). Thus the results show a reduction in employees in some years prior to the change in ownership.

The tables show that while some reductions occurred before the transition, the important changes happened during this period. For example, the average annual reduction during the pure public period was $6.6 \%$, while during the transition it was $9.9 \%$ per year, totaling an average reduction of the labor force by $38.1 \%$ during the transition in contrast with previous levels.

\section{Labor Productivity}

Consistent with the reductions in the number of employees and with the trends in output measures, labor productivity showed important improvements, mostly during the transition. Connections per employee as well as output per employee grew annually by $18.4 \%$ and $20.3 \%$, respectively, during the transition, but after these years, these ratios became $5.5 \%$ per year for both of them.

\section{Efficiency}

The results show that most of the improvement happened during the transition. While the average reduction in distributional losses was 5.5\% per year during the transition, during the periods before and after the annual change was only $0.6 \%$ and $-1.3 \%$, respectively. 


\section{E. Quality}

The quality measures were based on the duration and frequency of interruptions per consumer. Each indicator, on average, presented significant improvements across the transition and pure private periods. Both the duration and frequency of the interruptions were reduced during the transition, with an average total reduction of 30.6 points for duration and 34.9 points for frequency from the pure public levels of 134.5 and 132.6 points, respectively. The average annual improvement during the transition period was $9.8 \%$ for duration and $10.6 \%$ for frequency. In the pure private period, the trend for the duration of the interruptions was much flatter than during the transition, but the improvement per year was significantly higher than during pure public ownership. Meanwhile, frequency of interruptions continued its positive trend from the transition.

\section{F. Coverage}

Significant improvements across periods in coverage levels--as measured by residential connections per 100 households--can be observed in the growth rate of roughly $2 \%$ a year. However, the number of connections alone increased at a rate of $4-5 \%$. A likely explanation for the more rapid increase in connections than coverage is that most of the firms presented high coverage ratios $^{12}$ at the outset, so the "natural" growth in the number of households contributes to the increase in connections, rather than a net increase in coverage.

As Ros (1999) pointed out for privatizations in telecommunications, private ownership may lead to a different objective function that may negatively affect network expansion. This is because in a private company shareholders may be reluctant to increase the network unless it is profitable or made mandatory in the contract.

\footnotetext{
${ }^{12}$ Countries like Argentina, Brazil, Colombia, Panama and Chile had a coverage greater than $80 \%$ at the moment of the privatization. Peru, Nicaragua and Bolivia presented an average around 50\%, Guatemala $60 \%$, and Colombia and El Salvador 70\%.
} 


\section{G. Prices}

Average residential prices are presented both in dollars and in real local currency. Note that during the years surveyed, Brazil, which has a significant number of firms in the sample, suffered a currency devaluation. This occurred in 1999 and may partly explain the inconsistency in results when dollars were compared to local currency: while the prices in real local currency showed a clearly increasing trend, prices in dollars seemed to be decreasing in the same period. To correct for this discrepancy, the same methodology was repeated, excluding Brazil from the sample. This resulted in increasing prices in both series, but at a much lower rate than in the previous comparison. ${ }^{13}$ Both series also showed that prices increased significantly before the transition, with an annual growth of $9.3 \%$ and $10.2 \%$ for prices in dollars and real local currency, respectively. A pre-transition price increase could be attributed to the government's desire to make the company more attractive to investors by aligning cost and prices before awarding the concession.

Figure 2, shows the tendencies of each one of the analyzed indicators. The zero point in the horizontal axis denotes the time of the transaction or change of ownership.

Figure 2: Electricity Distribution
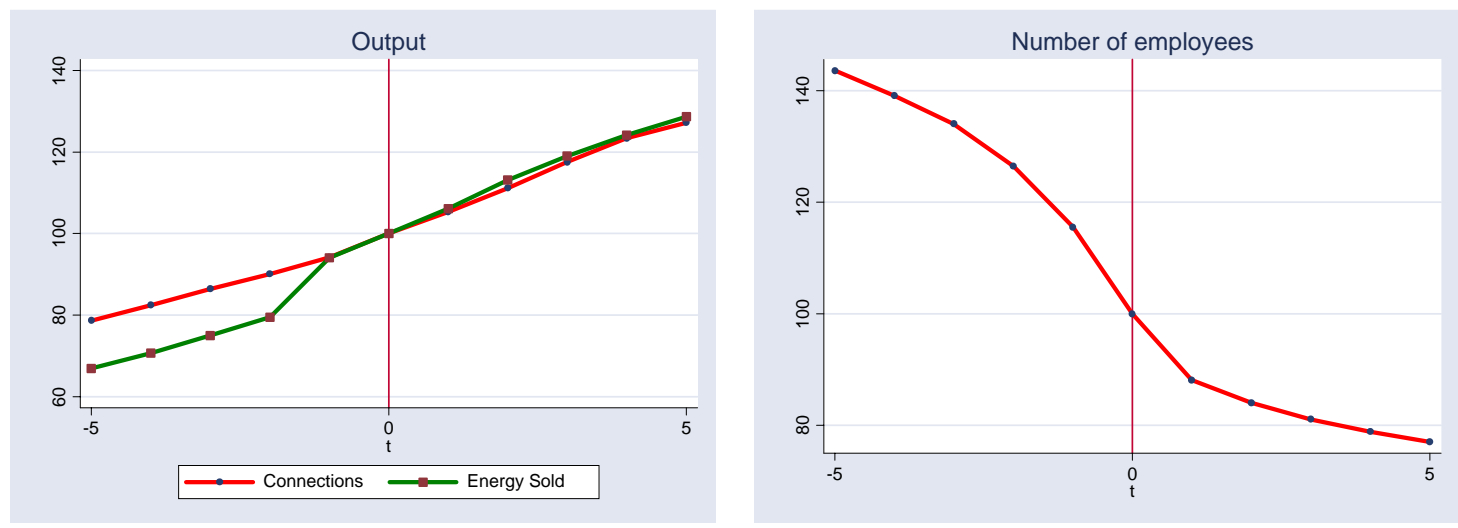

\footnotetext{
13 These tables are available upon request.
} 

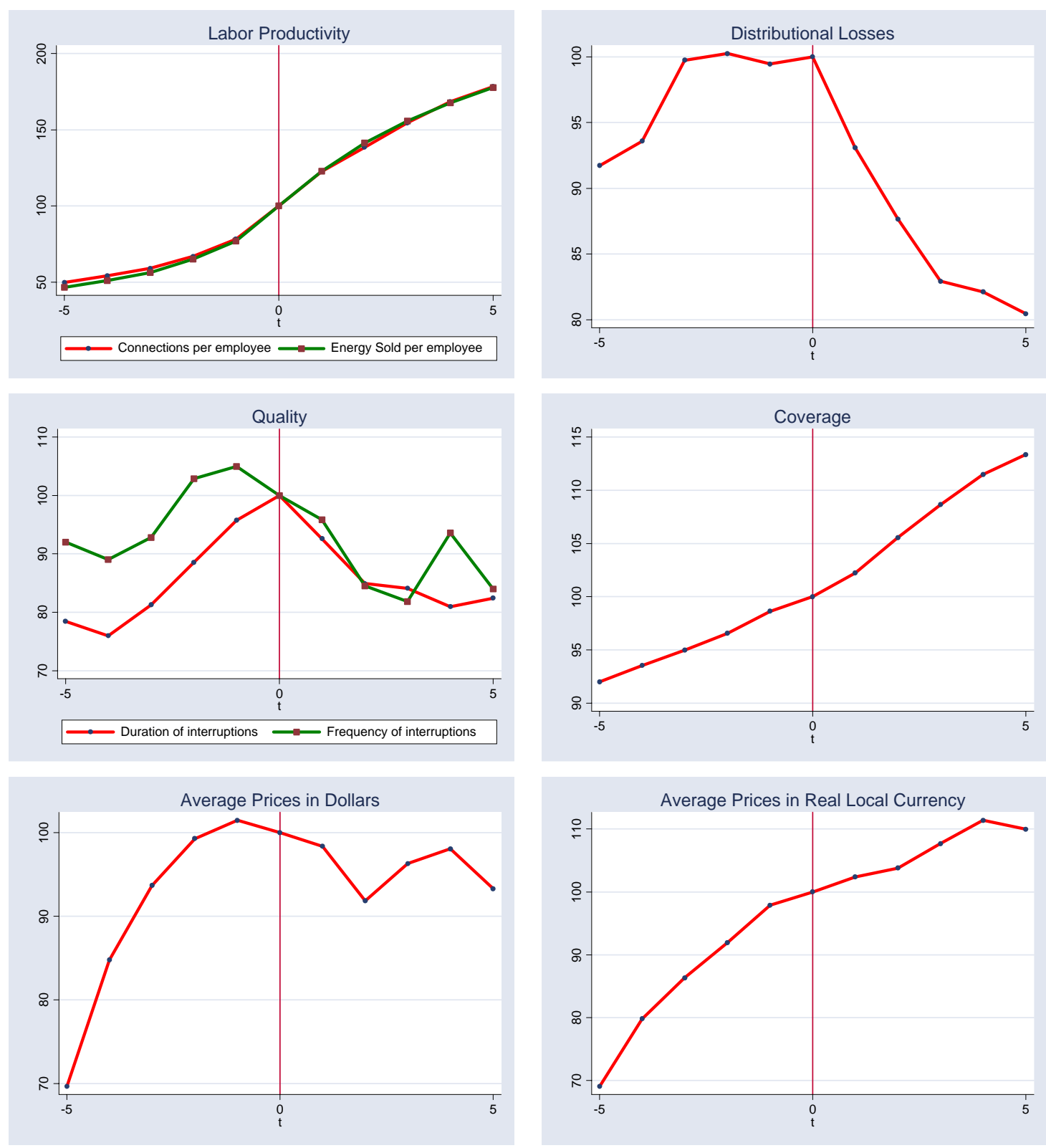

\section{V.2. Econometric Analysis}

In this section, the previous analysis is further developed, estimating several specifications for the indicators in both levels and rates of growth. To do this, a semi-logarithmic functional form was used in the models. These estimations were based on Feasible Generalized Least Squares (FGLS) estimates and included fixed effects for each firm.

For each set of indicators, the coefficients for the two main dummies are presented: DUM_PRIV_TR that has a value equal to one for all the years since the announcement of the 
concession $^{14}$ until one year after the change in ownership, and DUM_PRIV_POST that has a value equal to one for all the years after the transition period, which was defined as lasting one year after the change in ownership. Table 5 shows the basic results for each indicator under three different models: the estimates for the log levels without the firm-specific time trends, estimates with the firm-specific time trends, and estimates for the growth of each indicator as a dependent variable. Unless indicated otherwise in the text, results presented below are taken from the first model.

\footnotetext{
${ }^{14}$ As was already mentioned, the assumption is that the announcement was made two years prior to the award
} of the contract. 
Table 5: Electricity Distribution

\begin{tabular}{|c|c|c|c|c|c|c|c|c|c|c|c|}
\hline & $\begin{array}{c}(1) \\
\text { Number of } \\
\text { Connections }\end{array}$ & $\begin{array}{c}(2) \\
\text { Energy Sold } \\
\text { per year }\end{array}$ & $\begin{array}{c}\text { (3) } \\
\text { Number of } \\
\text { Employees }\end{array}$ & $\begin{array}{c}(4) \\
\text { Connections } \\
\text { per employee }\end{array}$ & $\begin{array}{c}\text { (5) } \\
\text { Energy per } \\
\text { employee }\end{array}$ & $\begin{array}{c}\text { Distributional } \\
\text { Losses }\end{array}$ & $\begin{array}{c}(7) \\
\text { Duration of } \\
\text { interruptions }\end{array}$ & $\begin{array}{c}\text { (8) } \\
\text { Frequency of } \\
\text { interruptions }\end{array}$ & $\begin{array}{c}(9) \\
\text { Coverage }\end{array}$ & $\begin{array}{c}(10) \\
\text { Avg price per } \\
\text { MWH } \\
\text { (in dollars) } \\
\end{array}$ & $\begin{array}{c}\text { (11) } \\
\text { Avg price per } \\
\text { MWH (in real } \\
\text { local currency) }\end{array}$ \\
\hline \multicolumn{12}{|c|}{ Model 1: Log levels without firm-specific time trend } \\
\hline $\begin{array}{l}\text { Transition } \\
(-2<=\mathrm{t}<=1)\end{array}$ & $\begin{array}{l}0.150 \star \star \star \\
(0.005)\end{array}$ & $\begin{array}{l}0.201^{\star \star \star} \\
(0.007)\end{array}$ & $\begin{array}{l}-0.307^{\star \star *} \\
(0.016)\end{array}$ & $\begin{array}{l}0.442^{\star \star *} \\
(0.019)\end{array}$ & $\begin{array}{l}0.474^{\star \star *} \\
(0.021)\end{array}$ & $\begin{array}{l}-0.031^{\star *} \\
(0.013)\end{array}$ & $\begin{array}{l}-0.144^{\star * \star} \\
(0.028)\end{array}$ & $\begin{array}{l}-0.107^{\star * \star} \\
(0.025)\end{array}$ & $\begin{array}{l}0.053^{\star \star *} \\
(0.004)\end{array}$ & $\begin{array}{l}-0.013 \\
(0.018)\end{array}$ & $\begin{array}{l}0.105^{\star \star \star} \\
(0.008)\end{array}$ \\
\hline $\begin{array}{l}\text { Post Transition } \\
(\mathrm{t}>=2)\end{array}$ & $\begin{array}{l}0.326^{\star * *} \\
(0.006) \\
\end{array}$ & $\begin{array}{l}0.370^{\star * *} \\
(0.008) \\
\end{array}$ & $\begin{array}{l}-0.500^{\star \star \star} \\
(0.018)\end{array}$ & $\begin{array}{l}0.810^{* * *} \\
(0.021) \\
\end{array}$ & $\begin{array}{l}0.819 * \star \star \\
(0.023) \\
\end{array}$ & $\begin{array}{l}-0.172^{\star \star \star} \\
(0.014)\end{array}$ & $\begin{array}{l}-0.488^{\star * \star} \\
(0.031)\end{array}$ & $\begin{array}{l}-0.415^{\star \star \star} \\
(0.028) \\
\end{array}$ & $\begin{array}{l}0.130 * \star \star \\
(0.004) \\
\end{array}$ & $\begin{array}{l}-0.041^{* *} \\
(0.019) \\
\end{array}$ & $\begin{array}{l}0.177^{\star \star \star} \\
(0.009)\end{array}$ \\
\hline Observations & 823 & 808 & 586 & 575 & 570 & 614 & 376 & 377 & 698 & 687 & 685 \\
\hline$\underline{\text { Log Likelihood }}$ & 1082.0 & 839.9 & 217.8 & 180.7 & 149.4 & 407.9 & 29.0 & 83.0 & 1185.8 & 315.2 & 677.4 \\
\hline \multicolumn{12}{|c|}{ Model 2: Log levels with firm-specific time trend } \\
\hline $\begin{array}{l}\text { Transition } \\
\quad(-2<=\mathrm{t}<=1)\end{array}$ & $\begin{array}{l}-0.002 \\
(0.002)\end{array}$ & $\begin{array}{l}0.040^{\star \star \star} \\
(0.005)\end{array}$ & $\begin{array}{l}-0.054^{\star \star *} \\
(0.013)\end{array}$ & $\begin{array}{l}0.049 \text { *** } \\
(0.012)\end{array}$ & $\begin{array}{l}0.086^{\star \star *} \\
(0.017)\end{array}$ & $\begin{array}{l}0.021 \\
(0.013)\end{array}$ & $\begin{array}{l}0.068^{\star *} \\
(0.033)\end{array}$ & $\begin{array}{l}0.076^{\star \star *} \\
(0.029)\end{array}$ & $\begin{array}{l}-0.007^{\star \star \star} \\
(0.002)\end{array}$ & $\begin{array}{l}0.078^{\star \star \star} \\
(0.012)\end{array}$ & $\begin{array}{l}0.034^{\star \star *} \\
(0.008)\end{array}$ \\
\hline $\begin{array}{l}\text { Post Transition } \\
\qquad(\mathrm{t}>=2)\end{array}$ & $\begin{array}{l}0.007^{\star *} \\
(0.003)\end{array}$ & $\begin{array}{l}0.026^{\star \star *} \\
(0.009)\end{array}$ & $\begin{array}{l}-0.007 \\
(0.022)\end{array}$ & $\begin{array}{l}0.013 \\
(0.022)\end{array}$ & $\begin{array}{l}0.006 \\
(0.030)\end{array}$ & $\begin{array}{l}-0.018 \\
(0.023)\end{array}$ & $\begin{array}{l}-0.047 \\
(0.055)\end{array}$ & $\begin{array}{l}-0.043 \\
(0.047)\end{array}$ & $\begin{array}{l}0.002 \\
(0.003)\end{array}$ & $\begin{array}{l}0.114^{\star \star *} \\
(0.018)\end{array}$ & $\begin{array}{l}0.041^{\star \star *} \\
(0.012)\end{array}$ \\
\hline Observations & 823 & 808 & 586 & 575 & 570 & 614 & 376 & 377 & 698 & 687 & 685 \\
\hline Log Likelihood & 2214.9 & 1415.6 & 723.3 & 623.4 & 541.9 & 736.9 & 138.8 & 230.7 & 1898.1 & 659.0 & 1046.0 \\
\hline \multicolumn{12}{|c|}{ Model 3: Growth } \\
\hline $\begin{array}{l}\text { Transition } \\
\quad(-2<=\mathrm{t}<=1)\end{array}$ & $\begin{array}{l}0.001 \\
(0.001)\end{array}$ & $\begin{array}{l}-0.002 \\
(0.003)\end{array}$ & $\begin{array}{l}-0.050^{* * *} \\
(0.008)\end{array}$ & $\begin{array}{l}0.048^{\star \star \star} \\
(0.008)\end{array}$ & $\begin{array}{l}0.046^{\star * \star} \\
(0.010)\end{array}$ & $\begin{array}{l}-0.042^{\star \star *} \\
(0.010)\end{array}$ & $\begin{array}{l}-0.063^{* * *} \\
(0.023)\end{array}$ & $\begin{array}{l}-0.050 \text { ** } \\
(0.024)\end{array}$ & $\begin{array}{l}-0.000 \\
(0.001)\end{array}$ & $\begin{array}{l}-0.117^{\star * *} \\
(0.011)\end{array}$ & $\begin{array}{l}-0.082^{\star * *} \\
(0.007)\end{array}$ \\
\hline $\begin{array}{l}\text { Post Transition } \\
\qquad(\mathrm{t}>=2)\end{array}$ & $\begin{array}{l}-0.003^{\star \star \star} \\
(0.001)\end{array}$ & $\begin{array}{l}-0.027^{\star \star \star} \\
(0.003)\end{array}$ & $\begin{array}{l}0.064^{\star * \star} \\
(0.008)\end{array}$ & $\begin{array}{l}-0.065^{\star \star \star} \\
(0.008)\end{array}$ & $\begin{array}{l}-0.092^{\star \star \star} \\
(0.010)\end{array}$ & $\begin{array}{l}0.015 \\
(0.010)\end{array}$ & $\begin{array}{l}0.001 \\
(0.021)\end{array}$ & $\begin{array}{l}-0.048^{\star *} \\
(0.021)\end{array}$ & $\begin{array}{l}-0.000 \\
(0.000)\end{array}$ & $\begin{array}{l}0.023^{\star \star \star} \\
(0.008)\end{array}$ & $\begin{array}{l}0.009 \\
(0.006)\end{array}$ \\
\hline Observations & 803 & 783 & 566 & 557 & 554 & 592 & 339 & 341 & 669 & 633 & 631 \\
\hline Log Likelihood & 1999.6 & 1265.7 & 575.0 & 486.7 & 401.5 & 486.6 & 16.6 & 56.1 & 1667.1 & 379.3 & 750.2 \\
\hline
\end{tabular}

* significant at $10 \%$; ${ }^{* *}$ significant at $5 \%$; ${ }^{* *}$ significant at $1 \%$
s. 


\section{A. Output}

While the first model of econometric analysis in Table 5 shows improvements in both the transition and pure private periods, the second and third models reveal that the increases of the transition period are not evident in the pure private period. In the first model, the average level of number of connections was $16.2 \%$ higher during the transition than during the previous period, and the average rise after the transition was $22.4 \%$ with respect to the previous period. The energy sold during these periods has a similar pattern in this model: While the average change during the transition was $22.3 \%$, for the following period it was $22.5 \%$ higher. These estimates suggest the potential existence of a time trend, which is confirmed by the results of the second model: After correcting for a time trend, the results imply that the effects of the change in ownership were negligible. Moreover, the third model, which shows differences in growth, confirms that there was a slight improvement in both energy sold and number of connections during the transition, but little significant change afterward.

\section{B. Number of Employees}

As is consistent with the previous analysis, a greater drop in the number of employees can be observed during the transition than during the pure private period.

More precisely, the electricity sector had an average annual drop of $26.4 \%$ in the number of employees during the transition with an additional annual decrease of $12.9 \%$ during the pure private period. ${ }^{15}$ The third model showed that while the rates of growth before and after the transition period did not differ significantly, the average annual reduction in growth rates during the transition was 5.7 percentage points.

\footnotetext{
15 The second panel also considered the firm-specific time trends. Though these coefficients were not reported in the tables, among the 66 firms with labor information, 16 companies presented coefficients not significantly different than zero. Among the rest of the companies, all but one had a significantly negative trend. The median in these cases was $-8.4 \%$ per year.
} 


\section{Labor Productivity}

The results for output and number of employees clearly influenced the labor productivity indicators. Overall, there appeared to be important improvements during the transition and pure private periods but further analysis revealed that the improvements occurred primarily during the transition.

More precisely, after controlling for trends, the resulting effects during the transition were annual increases of $5.0 \%$ for the connections-per employee ratio and $9.0 \%$ for energy-per employee, while the results for the following years were not significantly different than the averages before the transition. As is consistent with these outcomes, the annual growth estimates also increased during the transition: $7.3 \%$ for connections-per-employee and $7.5 \%$ for energy-peremployee. The growth rate of connections-per-employee dropped by $5.3 \%$ after the transition with respect to the first period. The results for energy-per-employee were not significant, although the rate appears to have declined.

Note that the labor productivity indicators were affected somewhat by the preparation of the firms to be sold. In some of the cases, the government decided to manage the labor force reform prior to the announcement of a proposed ownership change, with the intent to increase the value of the firm. As was analyzed by Chong and Lopez-de-Silanes (2003a), investors proved indifferent to these kinds of policies and, in the end, when all the components were included in the analysis, the values of the firms remained the same, or were even reduced in cases where the government applied lay-off programs in advance. A lay-off program can contribute to a reduction in a firm's value through selection issues that provide incentives for good employees to leave while bad employees remain in the company.

\section{Efficiency}

In addition to data on labor productivity, further analysis of additional features provides information on efficiency. An important reduction in distributional losses can be observed due to the change in ownership. One might assume that in order to improve performance, the firms would perform better maintenance and investments in the network, and the results would improve after the transitional years. The results of the analysis support this assumption: The total drop in distributional losses was only 3.1\% during the transition, but after that losses fell $15.8 \%$ from pure 
public levels. The growth estimates are consistent with these results, although the coefficients resulted in no significant differences from those for the first period.

\section{E. Quality}

The estimates show important improvements in frequency and duration of service interruptions due to the change in ownership both during the transition and after. More precisely, the average annual level of interruptions was reduced $10.1 \%$ for frequency and $13.4 \%$ for duration during the transition. After that, estimates show additional improvements of $23.8 \%$ and $25.2 \%$ for frequency and duration of interruptions, respectively. The growth estimates provide some evidence of the fact that the improvements were greater during the transition than during the pure public and pure private periods, though the results for frequency of interruptions were not significant.

\section{F. Coverage}

Given the population's natural growth, it is interesting to analyze the change in coverage in order to identify whether the expansion of the network was driven by the natural increase of households or by the net increase of the number of connections, as discussed in the previous section on coverage. Results suggest that there was a net expansion of the network, but growth in coverage did not vary greatly across periods.

The average annual increase in coverage was 5.3\% during the transition, while the average increase after that was $8.4 \%$ per year. However, the third model shows that the average growth across periods did not fluctuate significantly. This means that the changes across time in terms of coverage were driven by a firm specific time trend, and not necessarily by the change in ownership.

\section{G. Prices}

As described in the previous section, average prices were reported in dollars as well as in real local currency, and behaved differently in dollars because of the currency devaluation in Brazil that occurred during the years studied. The results of the econometric analysis show the important rise in prices that occurred during the years prior to the change in ownership; after that, prices continued to grow, but at lower rates.

Prices in real local currency were $11.1 \%$ higher per year during the transition as compared to the first period. After that, an additional 8.3\% annual increase was observed. However, the third 
model indicates that growth estimates are not significantly different before and after the transition, while during the transition itself, growth was slightly smaller.

\section{Additional Features}

An analysis of additional features can indicate the degree of robustness of the previous results. It is important to understand the arguments related to the endogeneity of the dummies used in the previous methodology.

In this kind of empirical analysis, several arguments support the presumption that the ownership dummies are endogenous. As was described by Ros (1999), the decision to privatize may not be viewed as an exogenous event that can be considered "fixed" in repeated sampling. Besides, there is the possibility of selection bias, though it can be argued that this possibility does not exist in this particular case. ${ }^{16}$ Several different hypotheses can make the case for endogeneity, such as the theory that the government privatizes those firms that are more likely to be sold. Secondly, countries under worsening financial conditions may have higher incentives to enact these reforms. Additionally, private investors may be more interested in firms that allow them to earn higher returns on their investment.

The basic approach is to use Instrumental Variables (IV) procedures. However, it is difficult to find proper instruments. In this case, macroeconomic variables were selected, as they are linked to the factors that cause governments to make these kinds of reforms, and they are, in general, independent of the variables under study. However, an additional problem arises given the fact that, in most of the countries, the companies were privatized in different years. To accommodate this variation, additional instruments are required, ideally at the state and/or city level. As collecting this state or municipal level data would be very difficult, the IV approaches were run using only the federal level variables, and the results are consistent with the previous analysis. ${ }^{17}$ Moreover, most of the coefficients resulted in higher absolute values, providing some evidence that the results of this paper are a lower bound than the total effect of the reforms.

\footnotetext{
${ }^{16}$ See Ros (1999, pp. 79) for a detailed explanation of this argument.

17 These tables are available upon request.
} 


\section{Conclusions}

This paper presents the analysis of the changes, as a result of private participation, in the performance of indicators in output, employment, labor productivity, efficiency, coverage and prices for 116 electricity distribution firms in Latin America. Two different methodologies were applied, and the effects during the transition period and those after it were separated.

The main contributions of this analysis to the literature are: The paper is a needed addition to the literature analyzing the electricity distribution sector, which has not been largely studied. Additionally, as opposed to the focus on financial outcomes in most of the literature, other indicators are introduced here that should be considered in impact evaluation studies. Finally, this analysis shows that it is important to separate short-term results from long-term ones, whereas most studies have focused only on short-term effects.

The results suggest that changes in ownership caused significant improvements in labor productivity, efficiency, and product/service quality in the near term. However, the improvements do not appear as remarkable two years after the change in ownership. This suggests that the change in ownership has the strongest effect on firms during the transition period. Figure 3 summarizes the main results where the arrows indicate the size and the direction of the changes in trends for each variable.

Figure 3: Summary of the main results: changes in trends

\begin{tabular}{|c|c|c|c|c|c|c|c|c|}
\hline & $\begin{array}{c}\text { Number of } \\
\text { subscribers } \\
\left({ }^{*}\right)\end{array}$ & $\begin{array}{l}\text { Output } \\
\left(^{\star}\right)\end{array}$ & $\begin{array}{l}\text { Number of } \\
\text { employees }\end{array}$ & $\begin{array}{c}\text { Labor } \\
\text { productivity } \\
\left({ }^{*}\right)\end{array}$ & $\begin{array}{l}\text { Distributional } \\
\text { losses }\end{array}$ & Quality & $\begin{array}{c}\text { Coverage } \\
\left(^{\star}\right)\end{array}$ & $\begin{array}{c}\text { Average } \\
\text { Prices }\end{array}$ \\
\hline Transition & & & & & & & & \\
\hline $\begin{array}{c}\text { Post } \\
\text { Transition }\end{array}$ & & & & & & & & \\
\hline
\end{tabular}

Note: $(*)$ these variables were reported after the firm-specific time trend consideration. The arrows indicate the the size and direcction of the changes for each variable.

Finally, although it was found that change in ownership matters, there seems to be some heterogeneity across firms regarding its impact. In order to explain that heterogeneity, further research is warranted focusing on differences among regulatory regimes, investors, financial structure, governance and country and sector characteristics. Those factors might explain some of the divergent results ${ }^{18}$.

\footnotetext{
${ }^{18}$ We are working on a second stage of this project that includes an analysis of the characteristics of the contracts between the government and the new owners, the privatization process, as well as the characteristics of the regulator, and how these features affect the results. We have found some preliminary evidence that these differences explain some of the heterogeneity (Andres, Foster and Guasch, 2006).
} 


\section{References:}

Andres, L., Vivien Foster, and J. L. Guasch (2006), The impact of Privatization on Firms in the Infrastructure Sector in Latin America Countries. The World Bank.

Bacon, R. W., and J. E. Besant-Jones (2001), "Global Electric Power Reform, Privatization and Liberalization of the Electric Power Industry in Developing Countries." Annual Review of Energy and the Environment 26, 331-59.

Boardman, Anthony and Aidan R. Vining (1989), “Ownership and Performance in Competitive Environments: A Comparison of the Performance of Private, Mixed, and State-Owned Enterprises,” Journal of Law and Economics, 32, pp. 1-33.

Chisari, O., A. Estache, and C. Romero (1997), "Winners and Losers from Utility Privatization in Argentina: Lessons from a General Equilibrium Model." Policy Research Working Paper 1824, World Bank, Washington, D.C.

Chong, Alberto and Florencio López-de-Silanes (2003a), “Privatization and Labor Restructuring around the World.” Manuscript. Yale University, New Haven, United States.

Chong, Alberto and Florencio López-de-Silanes (2003b), “The Truth about Privatization in Latin America”, Inter-American Development Bank, Latin American Research Network, Research Network Working Paper \#R-486, October.

D’Souza, Juliet and William L. Megginson (1999). “The Financial and Operating Performance of Newly Privatized Firms in the 1990s,” J. of Finance., 54, 1397-1438.

Dussan, M. (1996). “Electric Power Sector Reform in Latin America and the Caribbean.” Working Papers Series IFM-104.

Ehrlich, Isaac, Georges Gallais-Hamonno, Zhiqiang Liu, and Randall Lutter (1994), "Productivity Growth and Firm Ownership: An Empirical Investigation,” Journal of Political Economy, 102, pp. 1006-1038.

Estache, Antonio, Marco Manacorda and Tommaso M. Valletti (2002). "Telecommunication Reforms, Access Regulation, and Internet Adoption in Latin America”. Policy Research Working Paper 2802, March .

Estache, Antonio and Martin Rodriguez-Pardina (1998), "Light and Lightening at the End of the Public Tunnel: The Reform of the Electricity Sector in the Southern Cone," World Bank Working Paper, May.

Estache, Antonio and Martin Rossi (2004) "Have Consumers Benefited from the reforms in the Electricity Distribution Sector in Latin America?” Unpublished manuscript, The World Bank. 
Frydman, Roman, Cheryl W. Gray, Marek Hessel, and Andrzej Rapaczynski (1999), "When Does Privatization Work? The Impact of Private Ownership on Corporate Performance in Transition Economies,” Quarterly Journal of Economics, 114:4, pp. 1153-1191.

Galal, Ahmed, Leroy Jones, Pankaj Tandon and Ingo Vogelsang (1994), Welfare Consequences of Selling Public Enterprises, Oxford: Oxford University Press.

Galiani, Sebastián, Paul Gertler and Ernesto Schargrodsky (2004), “Water for Life: The Impact of the Privatization of Water Services on Child Mortality,” Journal of Political Economy.

Halvorsen, R and R. Palmquist (1980), “The interpretation of dummy variables in semi-logarithmic equations”, American Economic Review, 70, 474-475.

Heckman, James and Richard Robb (1985), “Alternative Methods of Evaluating the Impact of Interventions.” In James Heckman and Burton Singer, eds., Longitudinal Analysis of Labmy Market Data. New York: Cambridge University Press. 156-245.

Joskow, Paul (2003) "Electricity Sector Restructuring and Competition: Lessons Learned”. Cuadernos de Economía, Año 40, № 121, pp. 548-558 (diciembre ).

Kikeri, Sunita (1999), "Privatization and Labor: What Happens to Workers When Governments Divest?” World Bank Technical Paper 396. Washington, DC, United States: World Bank.

La Porta, Rafael and Florencio López-de-Silanes (1999), “Benefits of Privatization--Evidence From Mexico,” Q. J. Econ., 114:4, pp. 1193-1242.

Laurin, Claude and Yves Bozec (2000), "Privatization and Productivity Improvement: The Case of Canadian National (CN),” working paper, Ecoles de HEC, Montreal.

Megginson, William, Robert Nash and Matthias van Randenborgh (1994), “The Financial and Operating Performance of Newly Privatized Firms: An International Empirical Analysis.” Journal of Finance XLIX: 403-452.

Megginson, William and Jeffry Netter (2001), “From State to Market: A Survey of Empirical Studies on Privatization.” Journal of Economic Literature 39: 321-389.

Millan, J., E. Lora and A. Micco (2001). "Sustainability of the Electricity Sector Reforms in Latin America”. Research Department, Inter-American Development Bank.

Okten, Cagla and Peren Arin (2003) "How Does Privatization Affect Efficiency, Productivity and Technological Choice?: Evidence from Turkey”. Unpublished manuscript, Louisiana State University.

Ramamurti, Ravi (1996), Privatizing Monopolies: Lessons from the Telecommunications and Transport Sector in Latin America, Baltimore: Johns Hopkins University Press. 
Ros, Agustin (1999), “Does ownership or Competition Matter? The effects of telecommunications Reform on the Network Expansion and Efficiency”. Journal of Regulatory Economics; 15:6592.

Ros, Agustin and A. Banerjee (2000), “Telecommunications privatizations and tariff rebalancing: evidence from Latin America”. Telecommunications Policy 20 233-252.

Rossi, Martín (2004) “Ownership and Efficiency: Evidence from Latin American Electric Utilities”, Unpublished manuscript. University of Oxford.

Saal, David S. and David Parker (2001), "Productivity and Price Performance in the Privatized Water and Sewerage Companies of England and Wales”. Journal of Regulatory Economics: 20:1 61-90.

Wallsten, Scott (2001). “An econometric analysis of telecom competition, privatization, and regulation in Africa and Latin America”. Journal of Industrial Economics. Vol. 49, No. 1. March .

Wallsten, Scott (2002) "Does Sequencing Matter? Regulation and Privatization in telecommunications Reforms”, World Bank, February . 